\section{俩 Heighten Science \\ P U B L I C A T I O N S Corporation ISSN 2639-3182}

\title{
Allergic Asthma and Sick building syndrome
}

\author{
Seyyed Shamsadin Athari*
}

\begin{abstract}
Department of Immunology, School of Medicine, Zanjan University of Medical Sciences, Zanjan, Iran
\end{abstract}

\begin{abstract}
*Address for Correspondence: Seyyed Shamsadin Athari, Department of Immunology, School of Medicine, Zanjan University of Medical Sciences, Zanjan, Iran, Email: ss.athari@zums.ac.ir; ss.athari@gmail.com

Submitted: 17 December 2018

Approved: 10 January 2019

Published: 11 January 2019

Copyright: (C) 2019 Athari SS. This is an open access article distributed under the Creative Commons Attribution License, which permits unrestricted use, distribution, and reproduction in any medium, provided the original work is properly cited
\end{abstract}

Check for updates
Asthma is a complicated chronic disease of airway and airway inflammation, bronchoconstriction, cough, dyspnea and wheezing that are main symptoms of the asthma. Genetic, epigenetic and environmental agents are main factors in pathophysiology of the asthma. Direct and indirect healthcare costs and health-related quality of life in asthmatic patients require more and more attention. A main challenges of asthma control is environment and specially house and building [1].

Sick building syndrome (SBS) as a medical condition that leads to suffering of people from symptoms of illness in these building with no apparent reason. SBS symptoms are linked to time spent in a building and building conditions such as heating, ventilation, air condition systems and plan of building design are main causes of SBS symptoms. Sick Building Syndrome was coined in 1986 by WHO, when some health problems were observed in newly built buildings where had indoor air problems [2,3]. Aerosols and bio-aerosols have been produced in building, would be main triggers for increased incidence of allergic asthma and indoor allergens lead to appear of building-related symptoms in asthmatic patients. Also, presence of molds (fungi), pollen, bacteria and viruses in the moist air are correlated with inflammation of the respiration tract. Therefore, asthma and asthma-like symptoms are common in people who live in unstandardized buildings $[2,4,5]$.

Inadequate ventilation, chemical and biological contaminants from indoor or outdoor sources, unsuitable light intensity, polluted urban area location, higher temperature and humidity are important causes can be major trigger of SBS and in focus asthma. Therefore for prevention of problems in future, is necessary that check of contaminations source, attention to population susceptibility, monitoring people health and annually physically examination of building and workplace, employ medical and technical experts as building managers for using standard manufacturers and materials. With these offers, SBS can be prevented and asthma (especially allergic asthma) as important disease in recent years, would be controlled. At least, when building has unstandardized conditions and can produce hazardous particles, which can be trigger of asthma or increase asthma severity.

\section{References}

1. Athari AM, Afshari F, Eftekhari A, Athari SS. The surveillance system, diagnosis and treatment challenges of asthma and health policy orientation of main challenges. J Pain Manage Ther. 2017; 1: 1-5. Ref.: https://goo.gl/MqY25k

2. Crook B, Burton NC. Indoor molds, Sick Building Syndrome and building related illness. Fungal Biology Reviews, 2010; 24: 106-113. Ref.: https://goo.gl/tSukfp

3. Jansz J. Sick Building Syndrome. International Encyclopedia of Public Health (Second Edition) Elsevier. 2017; 502-505. 
4. Apter A, Bracker A, Hodgson M, Sidman J, Leung WY. Epidemiology of the sick building syndrome. J Allergy Clin Immunol. 1994; 94: 277-288. Ref.: https://goo.gl/JMu9vr

5. Norback D. An update on sick building syndrome. Curr Opin Allergy Clin Immunol. 2009; 9: 55-59. Ref.: https://goo.gl/pkyE4q 